\title{
Shewanella baltica strain JD0705 isolated from the mangrove wetland soils in Thailand and characterization of its ligninolytic performance
}

\author{
AIYA CHANTARASIRI \\ Faculty of Science, Energy and Environment, King Mongkut's University of Technology North Bangkok. \\ Rayong Campus, Rayong 21120, Thailand. Tel./fax.: +66-38-627000 ext.5446, ^email: aiya.c@ sciee.kmutnb.ac.th
}

Manuscript received: 28 November 2020. Revision accepted: 25 December 2020.

\begin{abstract}
Chantarasiri A. 2021. Shewanella baltica strain JD0705 isolated from the mangrove wetland soils in Thailand and characterization of its ligninolytic performance. Biodiversitas 22: 354-361. Lignin is a complex biopolymer and the third component by mass of lignocellulosic plant biomass. Its recalcitrant property hampers the hydrolysis and utilization of cellulose and hemicellulose in the lignocellulosic biomass. Thus, the delignification of lignocellulosic biomass is an enormous challenge for emerging bio-based applications. This study presented a potential ligninolytic bacterium for potential use in the biological delignification process under mild conditions. This bacterium was isolated from the mangrove wetland soils in Thailand, characterized and identified as psychrotrophic Shewanella baltica strain JD0705. It was determined for ligninolytic activity and showed laccase activity at $5.23 \pm 0.10 \mathrm{U} / \mathrm{mL}$. The optimum temperature and $\mathrm{pH}$ for the laccase activity were observed to be $25^{\circ} \mathrm{C}$ at a $\mathrm{pH}$ of 7.0 respectively with a stability range of $20-30^{\circ} \mathrm{C}$ temperature and $\mathrm{pH}$ of 7.0-8.0. S. baltica strain JD0705 was used in the biological delignification of rice husk powder and promoted the hydrolysis of rice husk powder to obtain more liberating sugar content. The findings from this study indicated that feasibility of using this ligninolytic bacterium for the production of laccase and the delignification of lignocellulosic plant biomass.
\end{abstract}

Keywords: Delignification, laccase, ligninolytic activity, mangrove wetland, Shewanella baltica

\section{INTRODUCTION}

Lignocellulosic biomass is the most abundant biopolymer in the world. It is comprised of carbohydrates and non-carbohydrate polymers, namely cellulose, hemicellulose, and lignin (Chantarasiri et al. 2017; Tsegaye et al. 2018). The lignocellulosic biomass has significant potential to serve as raw material for various anthropogenic activities, bio-based industries and the production of second-generation bioethanol. Cellulose is a homogenous hexose-based polysaccharide. Likewise, hemicellulose is a heterogeneous polysaccharide composed of pentoses, hexoses and acetylated sugars (Shen et al. 2010; Agbor et al. 2011; Tsegaye et al. 2018). Cellulose and hemicellulose have been hydrolyzed to liberate the sugars which play a vital role as feedstock in commercial usage and bioethanol production. Lignin is a recalcitrant component of lignocellulosic biomass. It has a complex structure of phenylpropane units bonded together by non-hydrolyzable carbon-carbon and ether bonds (Duval and Lawoko 2014; Chandel et al. 2015; Tsegaye et al. 2018). Lignin provides plants with compressive strength and protection from pathogens (Bandounas et al. 2011). At present, the environmental impacts of industrial and manufacturing processes are a global concern. Accordingly, the polysaccharides in lignocellulosic biomass have been converted into glucose and related sugars using an environmentally-friendly method such as enzymatic hydrolysis. A major limitation of the biological conversion of lignocellulosic biomass is the native characteristics of lignin. Lignin enfolds the polysaccharide structures and forms a physical recalcitrant barrier that significantly limits the enzymatic hydrolysis of the cellulose and hemicellulose in lignocellulosic biomass (Chandel et al. 2015). Delignification is required before the subsequent hydrolysis for enhancing enzyme accessibility and polysaccharide digestibility.

A variety of chemical methods are commonly applied for the removal of lignin surrounding the polysaccharide structures (Singh et al. 2014). Chemical delignification is considered as an uncomplicated, effective, and low-cost approach. However, it is harmful to the environment due to its corrosive and toxic properties. A more environmentallyfriendly method by ligninolytic enzymes is a promising technology for delignification since it is carried out in mild conditions and has no environmental impacts. Ligninolytic enzymes are released from lignin-degrading fungi such as white-rot fungi and lignin-degrading bacteria such as Streptomyces sp. (Bugg et al. 2011). Lignin-degrading microorganisms can primarily produce five ligninolytic enzymes including lignin peroxidase (LiP, EC 1.11.1.14), manganese-dependent peroxidase (MnP, EC 1.11.1.13), versatile peroxidase (VP, EC 1.11.1.16), laccase (Lac, EC 1.10.3.2) and dye-decolorizing peroxidases (DyPs, EC 1.11.1.19) (Datta et al. 2017). The advantage of lignindegrading enzymes from bacteria rather than fungi is that bacteria are much more supportable to genetic engineering and genetic modification in an industrial workhorse Escherichia coli (Chang et al. 2014). Nevertheless, studies on microbial ligninolytic enzymes have focused on fungal enzymes, while bacterial enzymes have seen little intensive study (Bugg et al. 2011; Chantarasiri et al. 2017; Janusz et al. 2017) 
One favorable environment for the occurrence of ligninolytic bacteria is the mangrove wetland ecosystems. Mangrove wetlands comprised of a unique aquatic ecosystem which is found along tropical and subtropical coastlines grown over by characteristic plants of the genera Rhizophora and Avicennia (Mitsch and Gosselink 2015; Chantarasiri 2015). Mangrove wetland soils are rich in organic carbon and lignin due to the litter of plant leaves, decaying woods, and underground roots of plants. These soils offer a favorable habitat for several ligninolytic bacteria such as Lysinibacillus sphaericus (Chantarasiri and Boontanom 2017), Mangrovibacterium lignilyticum (Sun et al. 2020), Streptomyces sp. (Kachiprath et al. 2019), and various species of Bacillus (Kachiprath et al. 2019). Therefore, the isolation of novel and effective ligninolytic bacteria from mangrove wetland ecosystems can be challenging.

This study aimed to isolate and screen ligninolytic bacteria from mangrove wetland soils in Rayong Province, Thailand. The most active ligninolytic bacterium was biochemically characterized and genetically identified by the nucleotide sequence analysis of the 16S rRNA gene. The ligninolytic activity of three enzymes including lignin peroxidase, manganese-dependent peroxidase, and laccase were determined. Finally, the ligninolytic bacterium was applied to biological delignification on lignocellulosic biomass. The results suggested that this bacterium could be considered a promising bacterium for the biological delignification of lignocellulosic biomass in various industrial applications.

\section{MATERIALS AND METHODS}

\section{Study area}

The study area was the Phra Chedi Klang Nam mangrove wetland in Rayong Province, located on the east coast of Thailand $\left(12^{\circ} 39^{\prime} \mathrm{N}, 101^{\circ} 14^{\prime} \mathrm{E}\right)$. This area was demonstrated as an identical area in the previous study of Chantarasiri (2015), which covers an area of 75,400 $\mathrm{m}^{2}$. This mangrove wetland is mostly grown over by halophilic plants including Avicennia alba Blume., Bruguiera gymnorrhiza (L.) Lamk. and Rhizophora apiculata Blume. The location of the study mangrove wetland is shown on a map in Chantarasiri (2015).

\section{Procedures}

Sampling of mangrove wetland soils

Thirty soil samples were randomly collected from the study area during the winter season in December 2015. Samples were taken at a depth of $0-5 \mathrm{~cm}$ to obtain primary aerobic ligninolytic bacteria. The lignin content in the surface soils was higher than the bottom soils because of the accumulation of decaying woods and plant litters. The samples were kept in sterilized plastic bags at $4^{\circ} \mathrm{C}$ and taken for bacterial isolation within $24 \mathrm{~h}$ of collection. Soil temperatures were measured at the collection sites by needle probe thermometer (Extech Instruments, USA). Soil $\mathrm{pH}$ values were determined from soil samples suspended in the neutral distilled water using a digital $\mathrm{pH}$ meter (Ohaus, USA).

\section{Isolation and colony purification of soil bacteria}

The isolation procedure of soil bacteria from collected samples was aligned with a previous study by Chantarasiri et al. (2017). One gram of each collected sample was suspended in $10 \mathrm{~mL}$ of sterilized Tryptone Soya Broth (HiMedia, India) at $\mathrm{pH} 6.7$ (the average $\mathrm{pH}$ of collected soil samples). All cultures were enriched at $27.3^{\circ} \mathrm{C}$ (the average temperature of soil measured at sampling sites) for $72 \mathrm{~h}$ on the shaking incubator at $150 \mathrm{rpm}$ (LSI-3016R shaking incubator, Daihan Labtech, Korea). The enriched cultures were serially diluted with sterilized $0.85 \%$ (w/v) $\mathrm{NaCl}$ solution to obtain 1:100,000 dilutions. Each diluted sample was spread plated on Tryptone Soya Agar (HiMedia, India) and incubated in an incubator (KB720 incubator, Binder, Germany), at $27.3^{\circ} \mathrm{C}$ for $24 \mathrm{~h}$. The isolated bacteria were selected based on their colony morphological dissimilarities and streak plated on Tryptone Soya Agar to obtain a pure bacterial colony. Finally, each pure bacterial colony was named for the isolation numbers.

Screening of ligninolytic bacteria by rapid RBBR method

The rapid RBBR method used for the detection of bacterial dye-decolorization/ligninolytic activity. This rapid screening method was adapted by Chang et al. (2014) and Chantarasiri et al. (2017) with minor modifications. A single colony of each isolated bacterium was inoculated in 5-mL BSGYP medium supplemented with $0.01 \%(\mathrm{w} / \mathrm{v})$ Remazol Brilliant Blue R dye (RBBR) (Sigma-Aldrich, Germany). The chemical composition of the BSGYP medium was previously described by Chang et al. (2014). The culture medium was subsequently incubated in the dark at $27.3^{\circ} \mathrm{C}$ for $72 \mathrm{~h}$ on a shaking incubator at $150 \mathrm{rpm}$. Bacterial cells were discarded from the medium by centrifugation at $12,000 \times \mathrm{g}$ for $10 \mathrm{~min}$ (Digicen 21R, Ortoalresa, Spain). Decolorization of RBBR was observed in the cell-free supernatant using the spectrophotometric method by a GENESYS ${ }^{\mathrm{TM}} 10 \mathrm{~S}$ Vis spectrophotometer (Thermo Scientific, USA) at a maximum wavelength of RBBR dye, $592 \mathrm{~nm}$. Control of the experiment was the uninoculated medium supplemented with RBBR. Finally, RBBR dye-decolorizing bacteria were considered as the ligninolytic bacteria based on the study of Chang et al. (2014).

The decolorization percentage was calculated using the following formula: Decolorization percentage $(\%)=\{$ $\left.\left(\mathrm{Abs}_{\mathrm{i}}-\mathrm{Abs}_{\mathrm{f}}\right) / \mathrm{Abs}_{\mathrm{i}}\right\} \times 100 . \mathrm{Abs}_{\mathrm{i}}$ is the initial absorbance of cell-free supernatant at $592 \mathrm{~nm}$ while $\mathrm{Abs}_{\mathrm{f}}$ is the final absorbance of cell-free supernatant after $72 \mathrm{~h}$ of incubation at $592 \mathrm{~nm}$. All experiments were assayed in triplicates. The most active ligninolytic bacterium was selected for the next experiment.

\section{Growth and biochemical characterization of bacterium isolate JD0705}

The bacterium isolate JD0705 was indicated as the most active ligninolytic bacterium obtained from the previous experiment. It was grown and characterized by culture in Tryptone Soya Broth under different conditions, including $\mathrm{pH}$ of $4.0-11.0$, a temperature between $20-55^{\circ} \mathrm{C}$ and $\mathrm{NaCl}$ concentration of $0-7.0 \%(\mathrm{w} / \mathrm{v})$. All cultures were incubated 
for $24 \mathrm{~h}$ on the shaking incubator at $150 \mathrm{rpm}$ and measured the bacterial growth by spectrophotometric method at 600 $\mathrm{nm}\left(\mathrm{OD}_{600}\right)$ after incubation. The number of the "+" symbol represents the bacterial concentration based on the $\mathrm{OD}_{600}$ value. "+" represents $\mathrm{OD}_{600}$ of $0.001-0.300$, while "++" represents $\mathrm{OD}_{600}$ of $0.301-0.800$, and "+++" represents $\mathrm{OD}_{600}$ more than 0.800 . All experiments were assayed in triplicates.

The anaerobic test was determined by Difco $^{\mathrm{TM}}$ Anaerobic Agar (Becton, Dickinson and Company, USA) in an anaerobic jar (Becton, Dickinson and Company, USA) supplemented with Anaerocult ${ }^{\circledR}$ A (Merck, Germany). The bacterial abilities to ferment sugars and produce hydrogen sulfide were analyzed by Triple Sugar Iron Agar (Himedia, India). Twelve biochemical characterizations were determined by using a KB013 identification kit (HiMedia, India), including malonate utilization, acetoin production, citrate utilization, $\beta$ galactosidase determination, nitrate reduction, catalase activity determination, arginine utilization and five carbohydrate utilization.

\section{Genetical identification of bacterium isolate JD0705}

Genomic DNA of bacterium isolate JD0705 was extracted by Genomic DNA Isolation Kit (Bio-Helix, Taiwan). Polymerase chain reaction (PCR) amplification of the 16S rRNA genes was carried out by using the OnePCR ${ }^{\mathrm{TM}}$ reaction mixture (Bio-Helix, Taiwan) with forwarding primer 27F (5'-AGAGTTTGATCMTGGCTCAG$\left.3^{\prime}\right)$ and reverse primer 1492R (5'TACGGYTACCTTGTTACGACTT-3') (Ferbiyanto et al. 2015). The PCR conditions were conducted from Boontanom and Chantarasiri (2020) for 35 amplification cycles in a Mastercycler ${ }^{\circledR}$ Nexus Gradient (Eppendorf, Germany). The PCR cycling was initialized by a preheating step at $94^{\circ} \mathrm{C}$ for $4 \mathrm{~min}$. Then, it was followed by a denaturation step at $94^{\circ} \mathrm{C}$ for $40 \mathrm{sec}$, an annealing step at $55^{\circ} \mathrm{C}$ for $60 \mathrm{sec}$ and an extension step at $72^{\circ} \mathrm{C}$ for 1 min 10 sec. The final extension step was performed at $72^{\circ} \mathrm{C}$ for 10 min. The 1,500-bp PCR products were electrophoresed on $1.0 \%$ (w/v) agarose gel (Merck, Germany) and visualized by Novel Juice (Bio-Helix, Taiwan). The PCR products were nucleotide sequenced using the services of the Thailand Institute of Scientific and Technological Research (TISTR) (Pathum Thani, Thailand) and repeatedly nucleotide sequenced using the services of Macrogen Inc. (Seoul, Korea). Nucleotide sequence similarity analysis of the PCR products was aligned at the National Center for Biotechnology Information (NCBI) using the BLASTn program based on the nucleotide collection (nr/nt) database and a megablast algorithm. A phylogenetic tree was generated by the NJ method with 100,000 bootstrap replications using SeaView program version 4.6.4 (Gouy et al. 2010) and visualized by FigTree software version 1.4.3 (Institute of Evolutionary Biology, University of Edinburgh, UK). Finally, the nucleotide sequence of bacterium isolate JD0705 was deposited in the GenBank database of NCBI under the accession number KY234388.
Preparation of crude ligninolytic enzymes for Shewanella baltica strain JD0705

The crude ligninolytic enzymes were prepared by following the method described in Chantarasiri et al. (2017) with minor modifications. Bacterium isolate JD0705 (designated as S. baltica strain JD0705 from mentioned identification experiment) was inoculated in 100-mL BSGYP medium at $\mathrm{pH} 7.0$ (the optimal $\mathrm{pH}$ of bacterial growth), which was supplemented with $0.01 \%$ (w/v) Kraft lignin (Sigma-Aldrich, USA). The bacteria were shake-flask cultured at $25^{\circ} \mathrm{C}$ (the optimal temperature of bacterial growth) for $48 \mathrm{~h}$ in an orbital shaking incubator at $150 \mathrm{rpm}$. The bacterial cultures were centrifuged at $15,000 \times \mathrm{g}$ at $4^{\circ} \mathrm{C}$ for $10 \mathrm{~min}$ to obtain cell-free supernatants. The supernatants were concentrated and partially purified by $10-\mathrm{kDa}$ Amicon ${ }^{\circledR}$ ultra centrifugal filter units (Millipore, Ireland) that finally served as the crude ligninolytic-enzyme solution.

\section{Determination of bacterial ligninolytic activities}

The ligninolytic activity assay of the crude enzyme was performed following the previously described studies (Yang et al. 2011; Chang et al. 2014; Chantarasiri et al. 2017). Lignin peroxidase was measured by incubating 1.5 $\mathrm{mL}$ of crude enzyme solution with $0.5 \mathrm{~mL}$ of reaction mixture containing $2.5 \mathrm{mM}$ 3,4-dimethoxybenzyl alcohol as substrate and $0.5 \mathrm{mM} \mathrm{H} \mathrm{H}_{2}$ as a cofactor. The lignin peroxidase reaction was spectrophotometrically measured at $310 \mathrm{~nm}$ for $5 \mathrm{~min}$. Manganese-dependent peroxidase activity was measured by incubating $1.5 \mathrm{~mL}$ of crude enzyme solution with $0.5 \mathrm{~mL}$ of reaction mixture containing $0.25 \mathrm{mM}$ phenol red as substrate, $0.1 \mathrm{mM} \mathrm{H}_{2} \mathrm{O}_{2}$ as a cofactor and $0.1 \mathrm{mM} \mathrm{MnSO} 4$ as natural mediator. The manganese-dependent peroxidase reaction was spectrophotometrically measured at $610 \mathrm{~nm}$ for $5 \mathrm{~min}$. Laccase activity was measured by incubating $0.2 \mathrm{~mL}$ of crude enzyme solution with $0.8 \mathrm{~mL}$ of reaction mixture containing $75 \mathrm{mM}$ catechol as substrate. Laccase reaction was spectrophotometrically measured at $440 \mathrm{~nm}$ for 10 min. One unit $(U)$ of enzyme activity was defined as the amount of enzyme catalyzing in $1 \mu \mathrm{mol}$ of substrates oxidized per minute of reaction. The assay buffer used in the reaction mixture was $50 \mathrm{mM}$ sodium phosphate buffer at a $\mathrm{pH}$ of 7.0. All experiments were assayed in triplicates.

\section{Characterization of the ligninolytic activity}

The characterization of the ligninolytic activity was examined on the crude ligninolytic enzymes produced from S. baltica strain JD0705. The study was based on its laccase activity under various temperatures and $\mathrm{pH}$ conditions. Activity was determined at a temperature ranging from $20^{\circ} \mathrm{C}$ to $55^{\circ} \mathrm{C}$ in $50 \mathrm{mM}$ sodium phosphate buffer at a $\mathrm{pH}$ 7.0. Thermal stability was measured by preincubating the crude enzyme at a temperature ranging from $20^{\circ} \mathrm{C}$ to $55^{\circ} \mathrm{C}$ for $24 \mathrm{~h}$ and determined the relative activity of laccase. The effect of $\mathrm{pH}$ on laccase activity and $\mathrm{pH}$ stability was performed in the $\mathrm{pH}$-varied buffers including $50 \mathrm{mM}$ citrate buffer $(\mathrm{pH}$ 4.0-5.0), $50 \mathrm{mM}$ sodium phosphate buffer ( $\mathrm{pH} 6.0-8.0)$ and $50 \mathrm{mM}$ glycine- $\mathrm{NaOH}$ buffer ( $\mathrm{pH}$ 9.0-11.0). The laccase activity was determined 
in the mentioned buffers at $25^{\circ} \mathrm{C}$. The $\mathrm{pH}$ stability was measured by pre-incubating the enzyme in the aforementioned buffer at $25^{\circ} \mathrm{C}$ for $24 \mathrm{~h}$ to determine the relative activity of laccase. All experiments were performed in triplicates.

\section{Application on biological delignification by Shewanella} baltica strain JD0705

The biological delignification on lignocellulosic biomass by ligninolytic $S$. baltica strain JD0705 was modified from a previously described study (Chang et al. 2014). Rice husk is a major by-product of the rice milling process and was selected as lignocellulosic biomass for this study. It contains approximately $40 \%$ cellulose and $30 \%$ lignin (Pacheco-Torgal et al. 2015). Rice husk biomass was collected from local rice-milling facilities in Rayong Province, Thailand. It was air-dried and ground to a particle size of 40 mesh. The rice husk powders were washed with tap water and dried in an air-forced oven at $60^{\circ} \mathrm{C}$ for $72 \mathrm{~h}$.

Two milliliters of log-phased S. baltica strain JD0705 were inoculated in $100-\mathrm{mL}$ Basal Mineral Medium (HiMedia, India) at $\mathrm{pH} 7.0$ supplementing with $3 \mathrm{~g}$ of rice husk powders as a sole carbon source. The bacteria were cultured at $25^{\circ} \mathrm{C}$ for $72 \mathrm{~h}$ in the orbital shaking incubator at $150 \mathrm{rpm}$. The biological delignification was terminated by heating the cultured medium at $100^{\circ} \mathrm{C}$ for $30 \mathrm{~min}$. The performance of biological delignification was indirectly determined by enzymatic hydrolysis of delignified rice husk powders. The enzymatic hydrolysis was followed by inoculating $10 \mathrm{U} / \mathrm{mL}$ of iKnowZyme cellulase (Reach Biotechnology, Thailand) in that Basal Mineral Medium and incubated at $50^{\circ} \mathrm{C}$ with the agitation of $100 \mathrm{rpm}$ for 12 h. The result of enzymatic hydrolysis was spectrophotometrically analyzed by determination of sugars released from the hydrolyzed rice husk powders using 3,5-dinitrosalicylic acid (DNS) method at $540 \mathrm{~nm}$ (Chantarasiri 2015). Control was the Basal Mineral Medium supplemented with rice husk powders without biological delignification. It was hydrolyzed by iKnowZyme cellulase under similar experimental conditions. All experiments were assayed in triplicates.

\section{Data analysis}

Statistical analysis was investigated by one-way ANOVA followed by Tukey's test with a 95\% confidence interval using $\mathrm{R}$ software version 4.0.0 ( $\mathrm{R}$ Foundation for Statistical Computing, Vienna, Austria).

\section{RESULTS AND DISCUSSION}

\section{Description of the collected soil samples}

Thirty soil samples were collected from the surface layer of soils of Phra Chedi Klang Nam mangrove wetland in Thailand. Soil textures were sandy and muddy clays. The average temperature of the collection points was $27.3^{\circ} \mathrm{C}$ and the average $\mathrm{pH}$ of the collected soil samples was 6.7. The average temperature and $\mathrm{pH}$ values were used as growth parameters for the following bacterial enrichment and isolation procedures.

\section{Isolation, colony purification, and screening of ligninolytic bacteria}

Forty-eight bacterial isolates with their colony morphological dissimilarities were isolated, colony purified, and named for the isolation numbers. The screening of isolated bacteria using the rapid RBBR method showed only five isolates that were defined as ligninolytic bacteria. Their RBBR decolorization percentage values ranged from $9.03 \pm 3.01 \%$ to $62.50 \pm$ $5.41 \%$, while the control was only $2.08 \pm 0.00 \%$ due to its spontaneous physicochemical decolorization. Notably, the bacterium isolate JD0705 showed a maximum RBBR decolorization percentage of $62.50 \%(p<0.001)$ within 72 $\mathrm{h}$ of incubation. Therefore, it was designated as the most active ligninolytic bacterium and selected for the subsequent experiments. Colony morphology and RBBR decolorization percentage values of five isolated ligninolytic bacteria are shown in Table 1. Colony morphology of bacterium isolate JD0705 on Tryptone Soya Agar incubated at $27.3^{\circ} \mathrm{C}$ for $24 \mathrm{~h}$ is shown in Figure 1A.

\section{Growth and biochemical characterization of bacterium isolate JD0705}

Bacterium isolate JD0705 was grown and characterized by culture in Tryptone Soya Broth under various conditions. The bacterial growth level was spectrophotometrically determined by $\mathrm{OD}_{600}$ after $24 \mathrm{~h}$ of incubation. The results showed that the isolate JD0705 could grow at a pH range from 6.0 to 9.0, a temperature from 20 to $30^{\circ} \mathrm{C}$, and a $\mathrm{NaCl}$ concentration from 0 to $4.0 \%$ $(\mathrm{w} / \mathrm{v})$. Its optimum growth conditions were $\mathrm{pH}$ of 7.0 , a temperature of $25^{\circ} \mathrm{C}$ and no $\mathrm{NaCl}$ supplemented in the culture medium. Therefore, it could be designated as a neutrophilic, psychrotrophic and halotolerant bacterium. The growth level of the bacterium isolate JD0705 is shown in Table 2.

Table 1. Colony morphology and RBBR decolorization percentage values of isolated ligninolytic bacteria from mangrove soil samples

\begin{tabular}{|c|c|c|c|c|c|}
\hline Bacterial isolate & Pigmentation & Shape & Margin & Elevation & $\begin{array}{c}\text { RBBR decolorization } \\
(\%)\end{array}$ \\
\hline JD0301 & Pale brown & Circular & Entire & Convex & $10.76 \pm 4.34^{\mathrm{ab}}$ \\
\hline JD0304 & White & Circular & Entire & Convex & $9.03 \pm 3.01^{\mathrm{a}}$ \\
\hline JD0306 & White & Circular & Entire & Convex & $20.14 \pm 2.17^{b}$ \\
\hline JD0705 & Pale brown & Circular & Entire & Convex & $62.50 \pm 5.41^{\mathrm{c}}$ \\
\hline JD1005 & White & Circular & Entire & Convex & $16.32 \pm 0.60^{\mathrm{ab}}$ \\
\hline
\end{tabular}

Note: Mean values of decolorization percentage followed by the same letter were not significantly different according to one-way ANOVA with Tukey's test $(p<0.05)$ analyzed by R software. RBBR decolorization experiment was assayed in triplicates 


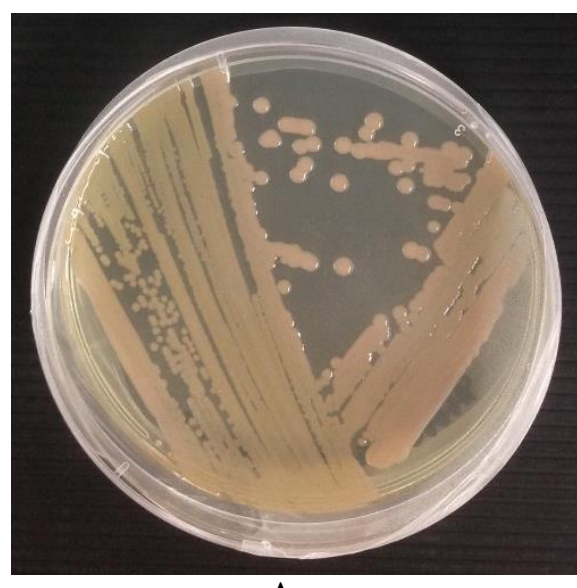

A

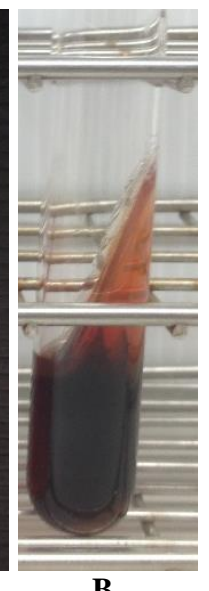

$\mathbf{B}$
Figure 1. A. Colony morphology of bacterium isolate JD0705 streak-plated on Tryptone Soya Agar. B. Bacterium isolate JD0705 cultured in Triple Sugar Iron Agar

Table 2. Growth (OD600) of bacterium isolate JD0705 cultured in Tryptone Soya Broth under various conditions

\begin{tabular}{cccccc}
\hline $\begin{array}{c}\text { pH } \\
\text { value }\end{array}$ & $\begin{array}{c}\text { Growth } \\
\text { level }\end{array}$ & $\begin{array}{c}\text { Temp. } \\
\left({ }^{\circ} \mathbf{C}\right)\end{array}$ & $\begin{array}{c}\text { Growth } \\
\text { level }\end{array}$ & $\begin{array}{c}\text { NaCl } \\
\text { conc. } \\
\mathbf{( \%} \\
\text { w/v) }\end{array}$ & $\begin{array}{c}\text { Growth } \\
\text { level }\end{array}$ \\
\hline $\mathbf{4 . 0}$ & - & $\mathbf{2 0}$ & ++ & $\mathbf{0}$ & +++ \\
$\mathbf{5 . 0}$ & - & $\mathbf{2 5}$ & +++ & $\mathbf{1 . 0}$ & ++ \\
$\mathbf{6 . 0}$ & + & $\mathbf{3 0}$ & + & $\mathbf{2 . 0}$ & ++ \\
$\mathbf{7 . 0}$ & +++ & $\mathbf{3 5}$ & - & $\mathbf{3 . 0}$ & ++ \\
$\mathbf{8 . 0}$ & ++ & $\mathbf{4 0}$ & - & $\mathbf{4 . 0}$ & + \\
$\mathbf{9 . 0}$ & + & $\mathbf{4 5}$ & - & $\mathbf{5 . 0}$ & - \\
$\mathbf{1 0 . 0}$ & - & $\mathbf{5 0}$ & - & $\mathbf{6 . 0}$ & - \\
$\mathbf{1 1 . 0}$ & - & $\mathbf{5 5}$ & - & $\mathbf{7 . 0}$ & - \\
\hline
\end{tabular}

The anaerobic test was determined by Difco $^{\mathrm{TM}}$ Anaerobic Agar and revealed that the isolate JD0705 was both an aerobic and anaerobic bacterium. The bacterial abilities to ferment sugars and produce hydrogen sulfide $\left(\mathrm{H}_{2} \mathrm{~S}\right)$ were investigated by Triple Sugar Iron Agar. The results indicated that the bacterium could not ferment any sugars including dextrose, lactose and sucrose. It was considered an $\mathrm{H}_{2} \mathrm{~S}$-producing bacterium due to its ability to produce the insoluble black precipitate of ferrous sulfide (FeS), as shown in Figure 1.B. The biochemical characterizations of the bacterium were determined by using a KB013 identification kit. It showed three strong positive reactions including arginine utilization, citrate utilization and nitrate reduction, while the other biochemical reactions were negative.

\section{Genetical identification of bacterium isolate JD0705}

Bacterium isolate JD0705 was genetically identified by PCR amplification and nucleotide sequence analysis of the $16 \mathrm{~S}$ rRNA gene. The nucleotide sequencing of the $16 \mathrm{~S}$ rRNA gene was performed in duplicate at the Thailand Institute of Scientific and Technological Research (Thailand) and Macrogen Inc. (Korea). The results obtained from nucleotide sequencing services were similar. Sequence alignment using the BLASTn program of NCBI showed that bacterium isolate JD0705 was closely related to Shewanella baltica strain 63 (NCBI reference sequence: NR_025267.1) with 99\% query coverage and $98.89 \%$ identity. The E value of the BLASTn alignment result was zero. A phylogenetic tree using the NJ method with 100,000 bootstrap replications is shown in Figure 2. The nucleotide sequence of bacterium isolate JD0705 obtained from this study was deposited in the GenBank database of NCBI under the accession number KY234388. Therefore, the bacterium isolate JD0705 was designated as $S$. baltica strain JD0705, which is classed as Gammaproteobacteria in the Phylum Proteobacteria.

\section{Ligninolytic activity of Shewanella baltica strain JD0705}

Crude ligninolytic enzymes were harvested from $S$. baltica strain JD0705 and determined for three ligninolytic activities including lignin peroxidase, manganesedependent peroxidase, and laccase. The results showed that $S$. baltica strain JD0705 could not produce lignin or manganese-dependent peroxidase. It could only produce laccase with an activity of $5.23 \pm 0.10 \mathrm{U} / \mathrm{mL}$. Therefore, $S$. baltica strain JD0705 was considered a laccase-producing bacterium. Its laccase was enzymatically characterized in various temperature and $\mathrm{pH}$ conditions. The effect of temperature on laccase activity was significantly at $25^{\circ} \mathrm{C}(p$ $<0.001)$ and $\mathrm{pH}$ at $7.0(p<0.001)$ (Figures $3 \mathrm{~A}$ and $4 \mathrm{~A})$. The enzyme was completely inactive at a temperature over $40{ }^{\circ} \mathrm{C}$ and either high acidic or high alkaline conditions. The laccase activity remained stable at up to $30^{\circ} \mathrm{C}(p<$ $0.001)$ and a $\mathrm{pH}$ range of 7.0-8.0 ( $p<0.001)$ (Figures 3B and $4 \mathrm{~B}$ ) after $24 \mathrm{~h}$ of incubation. As a result, this $S$. baltica laccase was apparently active and stable under conditions with ambient temperature and neutral $\mathrm{pH}$.

\section{Application on biological delignification by Shewanella baltica strain JD0705}

The rice husk powder was utilized for lignocellulosic biomass in this experiment. It was biologically delignified by ligninolytic $S$. baltica strain JD0705 and subsequently hydrolyzed by iKnowZyme cellulase to obtain fermented sugar. The amount of sugar released from the rice husk powder was measured after enzymatic hydrolysis using the DNS method. The delignified rice husk powder by $S$. baltica strain JD0705 was able to provide a sugar yield of $0.118 \pm 0.002 \mathrm{~g} / \mathrm{g}$ of biomass, while the undelignified rice husk powder yielded a sugar of $0.052 \pm 0.000 \mathrm{~g} / \mathrm{g}$ of biomass. The amount of sugar obtained from rice husk powder with biological delignification was approximately 2.27 times higher than that of the undelignified biomass. 


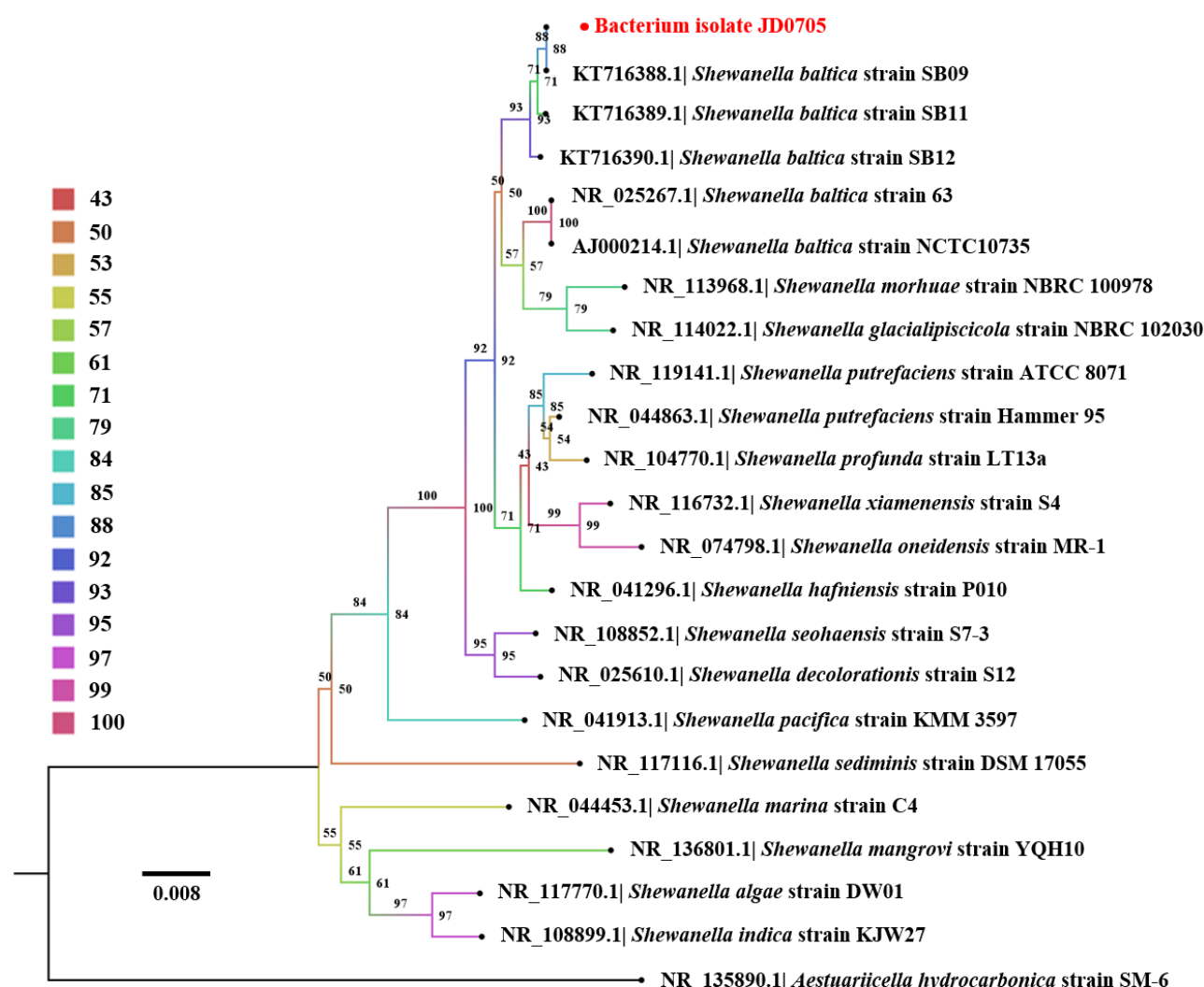

Figure 2. Phylogenetic tree of the 16S rRNA gene sequence of the bacterium isolate JD0705. The NJ method with 100,000 bootstrap replications was used in the inferred tree topology. The phylogenetic tree was generated and visualized by the SeaView program version 4.6.4 and FigTree program version 1.4.3. The color-coding represents bootstrap values
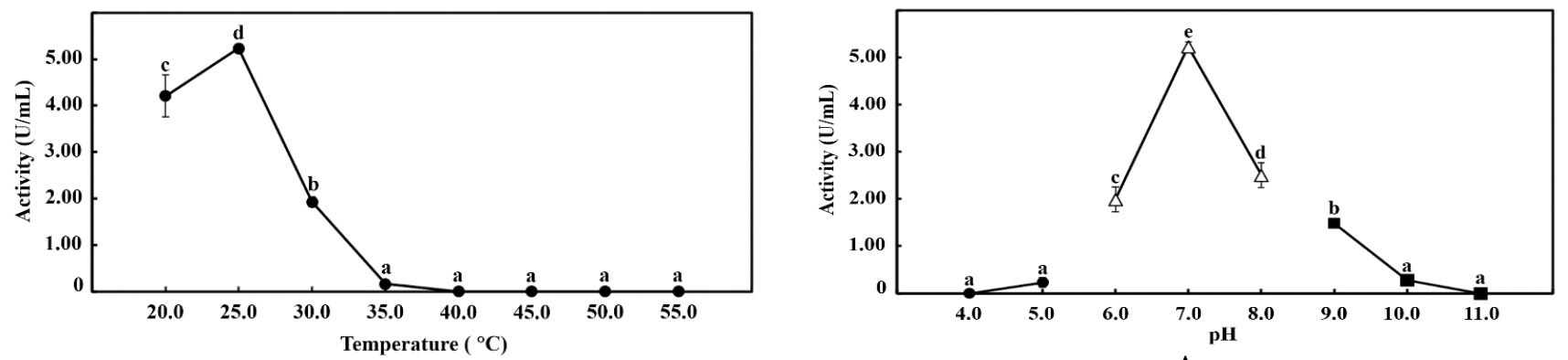

A
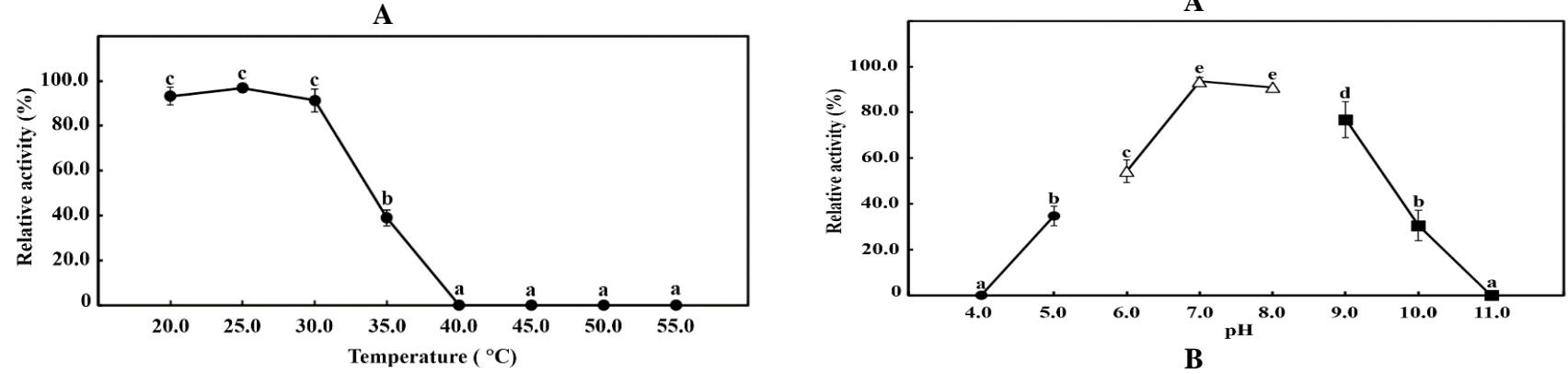

B

Figure 3. Effect of temperature on laccase activity (A) and stability (B) from Shewanella baltica strain JD0705. Error bars represent the standard deviation of the triplicates. The mean values followed by the same letter were not significantly different according to Tukey's test $(p<0.05)$ among the laccase activity. All experiments were assayed in triplicates

Figure 4. Effect of $\mathrm{pH}$ on the laccase activity (A) and stability (B) from Shewanella baltica strain JD0705. The activity of the enzyme was determined in a citrate buffer $(\bullet)$, sodium phosphate buffer $(\Delta)$ and glycine-NaOH buffer $(\boldsymbol{\square})$. Error bars represent the standard deviation of the triplicates. The mean values followed by the same letter were not significantly different according to Tukey's test $(p<0.05)$ among the laccase activity. All experiments were assayed in triplicates 


\section{Discussion}

Ligninolytic bacteria have seen minimal study and are not well understood. Therefore, bacterial ligninolytic potential remains largely unexplored and many novel ligninolytic enzymes may await discovery (Bandounas et al. 2011). These lignin-degrading bacteria represent three main classes: Actinomycetes, Alphaproteobacteria, and Gammaproteobacteria (Bugg et al. 2011; Janusz et al. 2017). In this study, the ligninolytic bacteria were isolated from mangrove wetland soils in Rayong Province, Thailand. The most active ligninolytic bacterium from the screening experiment was bacterium isolate JD0705. It was genetically identified as S. baltica strain JD0705 and growth characterized as a neutrophilic, psychrotrophic and halotolerant bacterium. It is evident that mangrove wetlands are a potentially promising ecosystem for ligninolytic bacteria isolation.

Shewanella is a genus of marine bacteria that belongs to the Gammaproteobacteria of Phylum Proteobacteria. Shewanella species have been recovered from fish, icedstored marine fish, marine animals and seawater. They have been described as rod-shaped, Gram-negative, $\mathrm{H}_{2} \mathrm{~S}$ producing, and psychrotrophic bacteria (Zhu et al. 2015). This complies with the characteristics and habitat of $S$. baltica strain JD0705 isolated from mangrove wetland soils in this study. Previous studies found that $S$. baltica was identified as a dominant species producing spoilage in icedstored marine fish caught in the Danish Baltic Sea and refrigerated large yellow croaker (Pseudosciaena crocea) (Gu et al. 2013; Zhao et al. 2016; Zhu et al. 2016). A recent finding reported that $S$. baltica was a normal flora living in mussels. It is a halotolerant spoilage bacterium that produces spoilage volatile metabolites during the cold storage of live mussels (Odeyemi et al. 2018). S. baltica is mentioned above as a psychrotrophic bacterium. It is generally isolated from low-temperature environments and marine-related sources. Novelistically, S. baltica strain JD0705 was isolated from the mangrove wetland ecosystem in a tropical zone.

S. baltica strain JD0705 was determined for ligninolytic performance. It could produce crude laccase with the satisfied enzymatic activity. Several Shewanella species have been isolated, explored for laccase production and genetically engineered. S. algae strain 1A02601 and $S$. marisflavi strain 1A02628 were isolated from marine environments in Xiamen, China. They demonstrated high laccase activities when grown under saline conditions (Liu et al. 2013). S. xiamenensis strain BC01 isolated from sediments in Xiamen, China was found to produce laccase activity when determined using 2,2'-azino-bis (3ethylbenzothiazoline-6-sulfonic acid) (ABTS) as a substrate $(\mathrm{Ng}$ et al. 2015). The laccase gene of $S$. putrefaciens strain ATCC 8071 was cloned and expressed by E. coli strain BL21 (DE3, pLysS) as a recombinant laccase for use in industrial applications (Sinirlioglu et al. 2013). Little is known about the laccase activity of $S$. baltica isolated from mangrove soil.

In this study, S. baltica strain JD0705 could not produce the other two ligninolytic enzymes including lignin and manganese-dependent peroxidases. The lack of peroxidases in this study might be described by the inappropriate compositions of the culture medium. According to a very recent study, the ligninolytic Klebsiella pneumoniae strain RY10302 reportedly produced only laccase when cultured in BSGYP medium supplemented with Kraft lignin (Chantarasiri 2020). Likewise, ligninolytic Streptomyces sp. strain S6 produced the highest activity for lignin peroxidase, slight laccase activity and no manganesedependent peroxidase activity when cultured in $\mathrm{W}$ minimal medium supplemented with Kraft lignin (Riyadi et al. 2020).

Crude laccase of S. baltica strain JD0705 was active and stable under ambient temperature and a neutral $\mathrm{pH}$. It is somewhat different from other bacterial laccases. To date, it has been reported that bacterial laccases predominantly come from Bacillus, Pseudomonas and Streptomyces (Christopher et al. 2014; Bu et al. 2020). Bacterial laccases are generally active and stable at nearnormal human body temperature and a neutral $\mathrm{pH}$. The optimal temperature for most bacterial laccases is between 37 and $40^{\circ} \mathrm{C}$ (Christopher et al. 2014). Their optimal pH is in the range of 6.5 and 7.6 (Christopher et al. 2014).

Laccases play a vital role in the depolymerization of lignin and its derivatives for delignification (Kumar and Chandra 2020). In this study, the laccase-producing $S$. baltica strain JD0705 was used to biologically delignify the rice husk powder. The hydrolysis result showed that the delignified rice husk powder yielded more fermented sugar than the undelignified biomass. Laccases depolymerize and degrade the lignin molecules by several subsequent mechanisms including the generation of phenoxy radicals, aromatic ring cleavage, alkyl-aryl cleavage, $c \alpha$-oxidation and $c \alpha-c \beta$ cleavage (Kumar and Chandra 2020). Laccases are considered as a green tool in various biotechnological processes in the near future (Giardina et al. 2010) because of their unique oxidizing mechanism and liberating only water molecules as the by-product (Kumar and Chandra 2020). Therefore, S. baltica strain JD0705 was preferred for the delignification activities of lignocellulosic biomass and related materials under mild conditions, without any additives or acid-base solutions.

In conclusion, mangrove wetlands are documented as a potential ecosystem for the isolation of ligninolytic bacteria. Ligninolytic bacteria can biologically delignify lignocellulosic biomass for various biotechnological applications, especially bio-based activities and bio-ethanol production. In this study, S. baltica strain JD0705 was isolated from the Phra Chedi Klang Nam mangrove wetland in Thailand and subsequently characterized. Infrequently, S. baltica strain JD0705 is a unique psychrotrophic bacterium due to its accidental isolation from the tropical temperature. S. baltica strain JD0705 was determined for ligninolytic performance and recorded as a satisfied laccase-producing bacterium. Finally, it could be used in the preliminary delignification of the rice husk powder. Further studies are suggested for the purification of laccase, improvement of laccase activity, and investigation of delignification performance in other lignocellulosic biomass. 


\section{ACKNOWLEDGEMENTS}

This research was funded by King Mongkut's University of Technology North Bangkok (contract no. KMUTNB-NRU-59-04). I am grateful to Ms. Parima Boontanom (ORCID 0000-0002-0278-9688) for kindly editing this manuscript.

\section{REFERENCES}

Agbor VB, Cicek N, Sparling R, Berlin A, Levin DB. 2011. Biomass pretreatment: Fundamentals toward application. Biotechnol Advances 29: 675-685. DOI: 10.1016/j.biotechadv.2011.05.005.

Bandounas L, Wierckx NJP, de Winde JH, Ruijssenaars HJ. 2011 Isolation and characterization of novel bacterial strains exhibiting ligninolytic potential. BMC Biotechnol 11: 94. DOI: 10.1186/1472 6750-11-94.

Boontanom P, Chantarasiri A. 2020. Short communication: Diversity of culturable epiphytic bacteria isolated from seagrass (Halodule uninervis) in Thailand and their preliminary antibacterial activity. Biodiversitas 21 (7): 2907-2913. DOI: 10.13057/biodiv/d210706.

Bu T, Yang R, Zhang Y, Cai Y, Tang Z, Li C, Wu Q, Chen H. 2020 Improving decolorization of dyes by laccase from Bacillus licheniformis by random and site-directed mutagenesis. PeerJ 8 e10267. DOI: $10.7717 /$ peerj.10267.

Bugg TDH, Ahmad M, Hardiman EM, Singh R. 2011. The emerging role for bacteria in lignin degradation and bio-product formation. Cur Opin Biotechnol 22: 394-400. DOI: 10.1016/j.copbio.2010.10.009.

Chandel AK, Gonçalves BCM, Strap JL, da Silva SS. 2015. Biodelignification of lignocellulose substrates: An intrinsic and sustainable pretreatment strategy for clean energy production. Crit Rev Biotechnol 35 (3): 281-293. DOI: 10.3109/07388551.2013.841638.

Chang YC, Choi D, Takamizawa K, Kikuchi S. 2014. Isolation of Bacillus sp. strains capable of decomposing alkali lignin and their application in combination with lactic acid bacteria for enhancing cellulase performance. Bioresour Technol 152: 429-436. DOI: 10.1016/j.biortech.2013.11.032.

Chantarasiri A. 2015. Aquatic Bacillus cereus JD0404 isolated from the muddy sediments of mangrove swamps in Thailand and characterization of its cellulolytic activity. Egyptian J Aquat Res 41 257-264. DOI: 10.1016/j.ejar.2015.08.003

Chantarasiri A. 2020. Klebsiella and Enterobacter isolated from mangrove wetland soils in Thailand and their application in biological decolorization of textile reactive dyes. Intl $\mathbf{J}$ Environ Res Public Health 17: 7531. DOI: 10.3390/ijerph17207531

Chantarasiri A, Boontanom P. 2017. Decolorization of synthetic dyes by ligninolytic Lysinibacillus sphaericus JD1103 isolated from Thai wetland ecosystems. AACL Bioflux 10 (4): 814-819.

Chantarasiri A, Boontanom P, Nuiplot N. 2017. Isolation and characterization of Lysinibacillus sphaericus BR2308 from coastal wetland in Thailand for the biodegradation of lignin. AACL Bioflux 10 (2): 200-209.

Christopher LP, Yao B, Ji Y. 2014. Lignin biodegradation with laccasemediator systems. Front Energ Res 2: 12. DOI 10.3389/fenrg.2014.00012

Datta R, Kelkar A, Baraniya D, Molaei A, Moulick A, Meena RS, Formanek P. 2017. Enzymatic degradation of lignin in soil: A review. Sustainability 9: 1163. DOI: 10.3390/su9071163.

Duval A, Lawoko M. 2014. A review on lignin-based polymeric, microand nano-structured materials. Reactive Funct Polymers 85: 78-96. DOI: 10.1016/j.reactfunctpolym.2014.09.017

Ferbiyanto A, Rusmana I, Raffiudin R. 2015. Characterization and identification of cellulolytic bacteria from gut of worker Macrotermes gilvus. Hayati J Biosci 22 (4): 197-200. DOI: 10.1016/j.hjb.2015.07.001.

Giardina P, Faraco V, Pezzella C, Piscitelli A, Vanhulle S, Sannia G. 2010. Laccases: a never-ending story. Cell Mol Life Sci 67: 369-385. DOI: 10.1007/s00018-009-0169-1

Gouy M, Guindon S, Gascuel O. 2010. SeaView version 4: A multiplatform graphical user interface for sequence alignment and phylogenetic tree building. Mol Biol Evol 27 (2): 221-224. DOI: 10.1093/molbev/msp259.

Gu Q, Fu L, Wang Y, Lin J. 2013. Identification and characterization of extracellular cyclic dipeptides as quorum-sensing signal molecules from Shewanella baltica, the specific spoilage organism of Pseudosciaena crocea during $4^{\circ} \mathrm{C}$ storage. J Agric Food Chem 61: 11645-11652. DOI: $10.1021 /$ jf403918x.

Janusz G, Pawlik A, Sulej J, Świderska-Burek U, Jarosz-Wilkołazka A, Paszczyński A. 2017. Lignin degradation: microorganisms, enzymes involved genomes analysis and evolution. FEMS Microbiol Rev 41: 941-962. DOI: 10.1093/femsre/fux049

Kachiprath B, Solomon S, Jayanath G, Philip R. 2019. Mangrove microflora as potential source of hydrolytic enzymes for commercial applications. Indian J Geo Mar Sci 48 (5): 678-684.

Kumar A, Chandra R. 2020. Ligninolytic enzymes and its mechanisms for degradation of lignocellulosic waste in environment. Heliyon 6: e03170. DOI: 10.1016/j.heliyon. 2020.e03170.

Liu G, Zhou J, Meng X, Fu SQ, Wang J, Jin R, Lv H. 2013. Decolorization of azo dyes by marine Shewanella strains under saline conditions. Appl Microbiol Biotechnol 97: 4187-4197. DOI: 10.1007/s00253-012-4216-8.

Mitsch WJ, Gosselink JG. 2015. Wetlands. Wiley, New Jersey.

$\mathrm{Ng} \mathrm{I}$, Xu F, Zhang X, Ye C. 2015. Enzymatic exploration of catalase from a nanoparticle producing and biodecolorizing algae Shewanella xiamenensis BC01. Bioresour Technol 184: 429-435. DOI: 10.1016/j.biortech.2014.09.079.

Pacheco-Torgal F, Lourenço PB, Labrincha JA, Kumar S, Chindaprasirt P. 2015. Eco-efficient Masonry Bricks and Blocks. Woodhead Publishing, Cambridge. DOI: 10.1016/C2014-0-02158-2.

Odeyemi OA, Burke CM, Bolch CJS, Stanley R. 2018. Evaluation of spoilage potential and volatile metabolites production by Shewanella baltica isolated from modified atmosphere packaged live mussels. Food Res Intl 103: 415-425. DOI: 10.1016/j.foodres.2017.10.068.

Riyadi FA, Tahir AA, Yusof N, Sabri NSA, Noor MJMM, Akhir FNMD, Othman N, Zakaria Z, Hara H. 2020. Enzymatic and genetic characterization of lignin depolymerization by Streptomyces sp. S6 isolated from a tropical environment. Sci Rep 10: 7813. DOI: 10.1038/s41598-020-64817-4

Shen DK, Gu S, Bridgwater AV. 2010. The thermal performance of the polysaccharides extracted from hardwood: Cellulose and hemicellulose. Carbohydrate Polymers 82: 39-45. DOI: 10.1016/j.carbpol.2010.04.018.

Singh R, Shukla A, Tiwari S, Srivastava M. 2014. A review on delignification of lignocellulosic biomass for enhancement of ethanol production potential. Renew Sustain Energ Rev 32: 713-728. DOI: 10.1016/j.rser.2014.01.051

Sinirlioglu ZA, Sinirlioglu D, Akbas F. 2013. Preparation and characterization of stable cross-linked enzyme aggregates of novel laccase enzyme from Shewanella putrefaciens and using malachite green decolorization. Bioresour Technol 146: 807-811. DOI: 10.1016/j.biortech.2013.08.032.

Sun C, Zeng X, Lai Q, Wang Z, Shao Z. 2020. Mangrovibacterium lignilyticum sp. nov., a facultatively anaerobic lignin-degrading bacterium isolated from mangrove sediment. Intl $\mathbf{J}$ Syst Evol Microbiol 70: 4502-4507. DOI: 10.1099/ijsem.0.004305.

Tsegaye B, Balomajumder C, Roy P. 2018. Biodelignification and hydrolysis of rice straw by novel bacteria isolated from wood-feeding termite. 3 Biotech 8 (10): 447. DOI: 10.1007/s13205-018-1471-0.

Yang YS, Zhou JT, Lu H, Yuan YL, Zhao LH. 2011. Isolation and characterization of a fungus Aspergillus sp. strain F-3 capable of degrading alkali lignin. Biodegradation 22: 1017-1027. DOI: 10.1007/s10532-011-9460-6.

Zhao A, Zhu J, Ye X, Ge Y, Li J. 2016. Inhibition of biofilm development and spoilage potential of Shewanella baltica by quorum-sensing signal in cell-free supernatant from Pseudomonas fluorescens. Intl J Food Microbiol 230: 73-80. DOI: 10.1016/j.ijfoodmicro.2016.04.015.

Zhu J, Huang X, Zhang F, Feng L, Li J. 2015. Inhibition of quorum sensing, biofilm, and spoilage potential in Shewanella baltica by green tea polyphenols. J Microbiol 53 (12): 829-836. DOI: 10.1007/s12275-015-5123-3.

Zhu J, Zhao A, Feng L, Gao H. 2016. Quorum sensing signals affect spoilage of refrigerated large yellow croaker (Pseudosciaena crocea) by Shewanella baltica. Intl J Food Microbiol 217: 146-155. DOI: 10.1016/j.ijfoodmicro.2015.10.020. 